\title{
THE ROLE OF ARTISTS IN THE PROCESS OF LEARNING CULTURAL AND DANCE ARTS SKILLS AT ELEMENTARY SCHOOL
}

\author{
Rakanita Dyah Ayu Kinesti \\ Institut Agama Islam Negeri Kudus \\ rakanita@iainkudus.ac.id
}

\begin{abstract}
This study aims to analyze the stages involved in the learning process and what arts and culture teachers do in their learning process. Researchers used qualitative research methods by taking research subjects at SD Negeri Pengkol, Kaliori District, Rembang Regency. The result was that the learning process was supported by formal education and non-formal education. Non-formal education had taken place in an artist's family environment or an art training environment (studio). In general, the artist's family would pass on the knowledge and skills they had mastered to their children. The artist's family hoped that his abilities would continue. Therefore, it was not surprising that dance skills, especially traditional and other dances, could be mastered well. The stages were carried out by the arts and culture teacher, namely the Dance Teacher, had applied the management method, organizing learning with the following stages: (1) the preparation stage, (2) the delivery stage, (3) the practice stage, and (4) the performance stage. Dance learning at SD Pengkol has a high carrying capacity both from the aspect of students, teachers, infrastructure, and the assessment system. Dance learning has a contribution both in terms of student competence and in supporting school activities as evidenced by various school achievements in the field of dance.
\end{abstract}

Keywords: The Role of Artists, Learning Cultural, Dance Arts Skills.

\begin{abstract}
Abstrak
Penelitian ini bertujuan untuk menganalisis tahapan-tahapan yang terlibat dalam proses pembelajaran dan apa yang dilakukan guru seni budaya dalam proses pembelajarannya. Peneliti menggunakan metode penelitian kualitatif dengan
\end{abstract}


mengambil subjek penelitian di SD Negeri Pengkol Kecamatan Kaliori Kabupaten Rembang. Hasilnya proses pembelajaran ditunjang oleh pendidikan formal dan pendidikan nonformal. Pendidikan nonformal telah berlangsung di lingkungan keluarga seniman atau lingkungan pelatihan seni (studio). Secara umum, keluarga seniman akan mewariskan ilmu dan keterampilan yang telah mereka kuasai kepada anak-anaknya. Keluarga artis berharap kemampuannya akan terus berlanjut. Oleh karena itu, tidak heran jika keterampilan menari khususnya tarian tradisional dan tari-tarian lainnya dapat dikuasai dengan baik. Tahapan yang dilakukan oleh guru seni budaya yaitu Guru Tari sudah menerapkan metode manajemen, menyelenggarakan pembelajaran dengan tahapan sebagai berikut: (1) tahap persiapan, (2) tahap penyampaian, (3) tahap latihan, dan (4) tahap pertunjukan. Pembelajaran tari di SD Pengkol memiliki daya dukung yang tinggi baik dari aspek siswa, guru, sarana prasarana, maupun sistem penilaian. Pembelajaran tari memiliki kontribusi baik dari segi kompetensi siswa maupun dalam menunjang kegiatan sekolah yang dibuktikan dengan berbagai prestasi sekolah di bidang tari.

Kata Kunci: Peran Seniman; Pembelajaran Budaya; Keterampilan Seni Tari.

\section{INTRODUCTION}

Cultural art education and skills as mandated in the Government Regulation of the Republic of Indonesia Number 19 of 2005 concerning National Education Standards are not only contained in one of the subjects because culture itself covers all aspects of life. In its course, PP 19/2005 concerning National Education Standards was later amended by Government Regulation (PP) Number 32 of 2013 concerning Amendments to Government Regulation Number 19 of 2005 concerning National Education Standards. In the subjects of Cultural Arts and Skills, the cultural aspects are not discussed separately but are integrated with art. And because of that, the subject of cultural arts and skills is basically the art education in which based on the culture. KTSP (Education Unit Level Curriculum) giving freedom to schools as places of learning and teachers as implementers of learning in the classroom to choose the learning materials in accordance with established basic competencies. To determine the learning materials must be in accordance with the curriculum, teaching methods, media, tools, and sources of materials that are in accordance with the conditions of students or learners.

The nature of art and culture, in general, is as individual expression, cultural expression, and local identity. The expected result of cultural arts education is not only making students become artists but also applying a sense of love for the 
cultural richness that exists in Indonesia. The subjects of cultural art consisting of fine arts, music, dance, theater, and crafts. Cultural Arts basically are the arts education that is based on the culture (because art is one of the cultural elements). As learning materials, the subject of Arts and Culture needs to be understood by the teacher, such as how to take the right methods to educate and shape children's character. This also underlies that learning is an effort to form students' character so that they can maintain culture in the midst of globalization (Rahayuningtyas et al., 2021). Arts and culture education and skills as mandated in the Government Regulation of the Republic of Indonesia Number 19 of 2005 concerning National Education Standards are not only contained in one subject because culture itself covers all aspects of life. In the subjects of Cultural Arts and Skills, the cultural aspects are not discussed separately but are integrated with art. Therefore, the cultural arts and skills subjects are basically culture-based arts education. Cultural literacy can hone and develop social skills for students (Ahsani \& Azizah, 2021).

Cultural Education, as stated by Ki Hajar Dewantara (in the Bastomi, 1993), are one of the factors in shaping the children's characteristic, because the art education at school could be made as to the educational base in shaping the character and personality. In line with this, Plato's statement (Rohidi, 2000 also reveals that art education can be used as the basis of education because it can be used to form a good personality. Because art education is an essential element in the process of forming the character of each individual, the existence of art education as a subsystem in national education cannot be ignored. Art education is a subject in schools because art education is multilingual, multidimensional, and multicultural. Multilingual means that arts aiming to develop the ability in expressing oneself by any means, such as fine art, sound, movement, and their combination. Multidimensional means that the arts developing students' basic competencies which include perception, knowledge, understanding, analysis, evaluation, appreciation, and productivity in balancing the right and left brain functions, by combining elements of logic, ethics, and aesthetics. While multicultural means that art aims to develop awareness and ability to appreciate the diversity of local and global cultures as the form of an attitude of respect, tolerance, democracy, civility, and living in harmony in a pluralistic society and culture (Depdiknas, 2001). 
The art subjects in school having function and purpose to developing characteristics and abilities so that the students are able to be creative and have sensitivity in arts, or giving the ability in creating and appreciating the arts. Both of these abilities are important because the dynamics of human social life and aesthetic values have a contribution to human happiness in addition to educating them. Art education materials in schools include music, dance, drama, and fine arts. In the 2006 Education Unit Level Curriculum (KTSP) art education in SD/ MI is carried out through arts and culture subjects and skills, which include subsubjects of fine arts, music, dance, and crafts. Dancing Art subject is one of the cultural arts sub-subjects included in the aesthetics subject group. This learning is intended to increase sensitivity, expressive ability, and ability to appreciate beauty and harmony. The ability to appreciate and expressing beauty and motion includes appreciation and expression in individual life so that they are able to enjoy and be grateful for life, as well as in social life, and are able to create harmonious togetherness (Tim Pustaka Yustsia, 2007).

In sub-district Kaliori, Rembang District, there are 26 elementary schools, and one of them is Pengkol elementary school. Pengkol elementary school is an elementary school where was located far away from the sub-district and the city. This elementary school often participates in competitions, either the academics or the non-academics. Moreover, in the dance competitions, it often becomes the winner in sub-district and regional competitions. This is proven by the students who excel in attending the regional sport and art event. Informal and non-formal learning activities at Pengkol Elementary school run smoothly and the tendency of students to be active and talented in arts and culture subjects especially in dance material. Art education at Pengkol Elementary school is not only given in form of informal learning activities but non-formal learning also takes place regularly as dancing extracurricular activities.

Dance as a branch of cultural arts taught in schools has a very important role in individual self-development, logical thinking skills, and the ability to develop self-potential which is continuously explored and developed based on the talents and creativity of the students. The learning process applies skills and uses facilities and follows a well-regulated mechanism in the RPP/SAP. A well-planned learning process will achieve the stated goals. In addition to 
implementing a well-organized learning process, one must always reciprocate and conduct studies to continue to improve the learning process. Process the electronic media according to the settings in SAP. The learning process through the internet encourages students to be more creative in doing homework assignments related to the internet or browsing, such as looking for pictures of the dance. The facility for the practical room also supports the students in the process of study. In Pengkol elementary school at Kaliori, they don't have their own practice room for the dancing subject, but the media that they use it's very complete from the tape recorder, DVD, tools for dancing practice such as sampur or dancing scarfs are available for the art subjects, especially the dancing art and the availability of the sampur for the students who don't have it. Furthermore, they also have their own dancing costume to facilitate the students when participating in dancing competitions and events. The teacher and students carrying out the learning activities in their classroom that has been sorted out so the learning process of practice activities conducive.

Learning (instruction) is the accumulation from the teaching concept (teaching) and the learning concept (learning) emphasized on the combination of both, which is on the growth of students activities. Such a concept could be viewed as a system, so in the learning, the system consists of students' components, goals, and the materials to achieve the goals, facilities, and the procedures, and also the tools and media that have to be prepared. As stated by Davis, (1974: 30) that the learning system is concerning the organizing from the combinations of the human, learning experience, facilities, maintenance or control, and the procedures which regulate the interaction of learning behavior to achieve the goals. Likewise with the teaching system, where the components of teaching planning, teaching materials, material objectives. The methods, as well as the assessment and teaching steps, will relate to learning activities to achieve the goals. The fact that in the learning process there is organizing, managing, and transforming information by and from teachers to students. The three categories of activities in the learning process are related to the application and concept of management information systems.

Based on the results of previous research on the stages that must be taken in learning cultural arts, (Sustiawati dkk, 2018) explained that there are stages made 
by the curriculum in regulating teachers to teach cultural arts, especially regional dance. However, of course, implementing this curriculum requires complete books and teaching materials, and special teachers are needed to teach the art. Seeing some of these ornaments, learning art and culture in Indonesia, especially elementary schools, still does not meet the criteria made by the curriculum. This is in line with (Soetopo, 2015) regarding the need for complete teaching materials to support this cultural arts learning process. Meanwhile, (Kusumastuti, 2014) explains that in teaching cultural arts, two general stages are needed, namely the existence of scientific disciplines and the approach taken by the teacher of cultural arts subjects themselves.

Based on some of the results of the research above, in the process of learning arts and culture, especially dance, disciplines are needed as well as complete textbooks. There are several stages provided by the curriculum but have not been fully implemented during the learning process. This study focuses more on how the stages of the dance learning process are carried out by teachers at Pengkol Elementary School, Kaliori sub-District, Rembang Regency.

\section{METHODS}

The research of the implementation of the cultural arts learning process (dance art material) at Pengkol Elementary School, Kaliori sub-District, Rembang Regency uses a qualitative method with the object of research being the Cultural Arts Learning Material for Dance. The qualitative nature of the research leads to the quality and depth of the description, namely a discussion of the implementation of the Cultural Arts learning process (Dance Art Material) at Pengkol Elementary School, Rembang Regency, which is described according to the conditions in the field. The data in this study are divided into primary and secondary data. The primary data is the steps which are carried out by the teachers when the dance lesson takes place. The secondary data is the additional data in the form of teaching materials, teacher handbooks, learning models, and the learning media.

The researchers using Observation and Documentation instruments (Audio, Video, Pictures) in obtaining data. According to (Hasanah, 2017) observation is direct observation with or without any interaction with the object of the 
research. These observations were made intentionally and sequentially based on the research objectives. (Syamsudin, 2014) explains that during research, the researchers must have notes in the form of descriptive writing or checking lists to make it easier for researchers to find whether or not the data they are looking for is in accordance with the research objectives.

The tests of data validity were also carried out by researchers with the aim that the data obtained by researchers did not differ from the data that actually occurred. That way, the results of this study are certainly presented with accountability. Researchers pay attention to data collection in accordance with the object of research. Using records that actually happened, proven by complete documentation as corroborating data. In addition, in order not to reduce the validity of the data, the researchers also conducted research on time according to the plan in the study.

The data analysis technique in this study uses an inductive qualitative analysis, which is an analysis based on the data obtained, then a certain relationship pattern is developed. The steps that must be conducted in data analysis are data reduction, data display, and conclusion drawing or verification (Nasution, 1999). In addition, (Sugiyono, 1998) suggests that activities in qualitative data analysis are carried out in an interactive manner and continued until they are complete so that the data is full. The activities during data analysis, namely data collection data, data display, and conclusion drawing or verification.

\section{RESULTS AND DISCUSSION}

After conducting the research and obtaining the data, the researcher had obtained the process of cultural art learning (dance material) in Pengkol elementary school, Kaliori sub-district, Rembang regency. The research purpose was to analyze the steps that had been conducted by the cultural art teachers in the learning process in the classroom. The steps that had been conducted by the art teachers, which was the dancing teacher, were management method, organizing the learning with the steps of (1) preparation phase, (2) delivery phase, (3) practice phase, and (4) appearance phase. The dance learning in Pengkol elementary school had a high support system, whether, from the students, teachers, tools 
and media, and assessment system, even the cultural art learning also was written stated in the school vision which was piety, achievement, and cultured in the spirit of global excellence. The learning assessment had been conducted by the teacher by using many ways, such as a daily exam, mid-semester exam, end of semester exam, class promotion exam, and school exam. Learning Assessment was carried out by the principal or supervisor. Dance learning had a contribution both in terms of student competence and in supporting school activities was as proven by various school achievements in the field of dance.

Learning was a process of interaction between students and educators and learning resources in a learning environment. 9 Learning SBK (Cultural Arts and Skills) was a subject at the SD/MI level. This subject was one of the lessons which could save the arts and culture of Indonesian heritage from the development of modern times. Arts and culture education and skills had as mandated in the Government Regulation of the Republic of Indonesia in Number 19 of 2005 concerning National Education Standards were not only contained in one subject but also culture itself covers all aspects of life. In the subjects of Cultural Arts and Skills, cultural aspects were not discussed separately but were integrated with art. Therefore, arts and culture subjects and skills were basically culture-based arts education. Naisah (2013) suggested that the existence of the cultural art and skills subjects aimed so the students having these competencies: Understand the concept and the importance of cultural art and skills. Displaying an attitude of appreciation for cultural art and skills. Displaying through cultural art and skills. Demonstrate participation in cultural art and skills at the local, regional, even global level.

\section{The Scope Of Cultural Art and Skills}

According to KTSP, the scope of cultural art and skills subjects covered the following aspects:

a. The Fine Art, including the knowledge, skills, and value were in creating arts in the form of paintings, sculptures, carvings, prints, and so on.

b. Music, including the ability to master vocals, played musical instruments, was the appreciation of musical works. 
c. Dance, which included movement skills based on body exercise with and without sound stimulation, was the appreciation of dance movements.

d. Dramatic arts, including staging skills by combining the arts of music, dance, and acting.

Art education in elementary schools had a role in developing the child's personality. In addition, art education also influences the other subjects in school. According to Art and Everyday Life in the Depdiknas (2007: 5) stated that: "... arts lessons correlated with the other subjects. But from other literature, it could be revealed that art lessons function as a transfer of learning and transfer of value of the other discipline knowledge". The development of art education showed that art education had changed from time to time, both in terms of concepts and activities. The development of attitudes in the arts, sensibility, and creativity, the establishment, and motivation of children in expressing naturally, uniquely, spontaneously were some of the aspects that were directed in art education in elementary schools. It was stated in Law Number 20 of 2003 concerning the National Education System that: "the purpose of children's education was developing the full potentials optimally to form a behavior and basic competency which appropriated to their level of development". The opinion above was a reference in the purpose of learning art in elementary schools that children should be given the freedom to develop creative expression and artistic potential, as well as foster the skills and abilities of children to interact with the environment. As for the function of art education according to (Tumurang, 2006) were:

\section{Medium of Expression}

From a language perspective, an expression was an expression. If elaborated further, the expression was the delivery of something from one person to another. (Soehardjo, 2012) viewed the relationship of expression as an expression of one's feelings as he stated that: The expression of life had started since humans were born in the world, for example when babies could not speak and use signs to their mothers because they wanted something. Expressions which were shown by children were usually the desire to achieve certain goals, such as satisfying hunger or even expressing the emotions they were feeling. 
Learning (instruction) was an accumulation of the concept of teaching (teaching) and the concept of learning (the emphasis lied in the combination of the two, namely the growth of students' activities. The concept could be viewed as a system so that in this learning system there were components of students, materials to achieve goals, facilities, and procedures as well as tools or media that should be prepared. This information organizing skill was the basis for the smooth learning process. (Agnew et al, 1996) stated that learning was the ability to be able to organize information which is fundamental for a student. (Meier, 2002) suggested that all human learning essentially had four elements, namely preparation, presentation, training (practice), and performance.

In the learning process included activities from opening to closing learning. The learning activities included (1) initial activities, which we're doing apperception, conveying learning objectives, and if deemed necessary giving a pretest; (2) core activities, that was the main activities were carried out by teachers in providing learning experiences, through various strategies and methods that were considered in accordance with the objectives and materials to be delivered; (3) the final activity was concluding learning activities and giving assignments or homework if deemed necessary.

The preparation stage was concerned with preparing learning participants to learn. Without it, learning would be slow and might even stop altogether. However, because they were too eager to get material, this stage was often neglected, thus interfering with a good lesson. Preparation for learning was like preparing the soil for planting seeds. If it was done correctly, it undoubtedly created good conditions for healthy growth. Likewise, in mature learning according to the characteristics of needs, materials, methods, approaches, environment, and teaching abilities, the results were assumed to be more optimal. This stage was important given that to face all kinds of obstacles that could potentially interfere, such as not feeling the benefits, fear of failure, hate on the topic of the lesson, being forced to attend, feeling that they had already known, and feeling bored. All of these and other obstacles could cause stress, strain, and a decline in learning abilities.

Based on the above, the purpose of the preparation stage was to arouse the interest of the learners, gave them positive feelings about the upcoming learning experience, and place them in an optimal situation for learning. This could be 
done by giving positive suggestions, providing useful statements, providing clear and meaningful goals. This stage also aimed to arouse curiosity, create a positive physical, emotional, social environment. Calms fear, removed learning barriers, asks lots of questions and raised various problems, stimulates curiosity, and invites full learning from the beginning. Many people had negative feelings about studying, their unconscious memories associate learning with pain, humiliation, confinement, and so on. If they didn't replace these negative suggestions with positive ones, their learning will be hindered. This was because such negative images tend to color the experience with assumptions.

Negative assumptions tended to create negative experiences and positive assumptions tended to create positive experiences. Suggestions should not be excessive, giving the impression of being stupid, shallow, but should be realistic, honest, and not long-winded. In any event, if you were determined to achieve positive things, positive results would likely be achieved. When negative assumptions had been replaced with positive ones, a sense of joy and relief could accelerate their learning (Merton in the MKDP Curriculum \& Development Team, 1986).

The delivery stage in the learning cycle was intended to bring together learning participants with learning materials that initiated the learning process positively and interestingly. The delivery stage in learning was not just something that the facilitator did, but something that actively involved learning participants in creating knowledge at every step. While the purpose of the delivery stage was to help participants learn to find new learning material in a way that was interesting, fun, relevant, involved the five senses, and was suitable for all learning styles.

This exercise stage was in the learning cycle affects $70 \%$ or more of the overall learning experience. It was at this stage that real learning had taken place. After all, it was what learners thought, said, and did that created learning and not what instructors or educators thought, said, and did.

The teacher's role was to invite new learners to learn in a way that helped to integrate them into the internal structure of meaning knowledge and skills embedded within them. The purpose of the research phase was to help learning participants integrate and absorbed new knowledge and skills in various ways (Naisah, 2013). Such as processing activities, games in learning, problem-solving activities, individual reflection and articulation, dialogue in pairs or groups, 
learning, and collaborative review including practical activities in building other skills. Learning was the process of turning experience into knowledge, knowledge into understanding, understanding into wisdom, and wisdom into action. The purpose of this output stage was to ensure that learning remains embedded and was successfully applied. After experiencing the first three stages of the learning cycle, we needed to ensure that people applied their new knowledge and skills to their work, real values for themselves, the organization, and the organization's clients. TheSteps of Cultural Arts Learning (dance material) at Pengkol Elementary School, Kaliori Sub-district, Rembang Regency. The implementation of cultural arts learning (dance material) has several stages, namely:

\section{Preparation Stage}

In the preparation stage, the teacher preparing learning included:

a. Preparing Annual Program (Prota)

The annual program was a learning program for all Competency Standards (SK) and Basic Competencies (KD) which should be taught for 1 year. Basic Competence was a description of each Competency Standard. In the annual program, SK and KD were divided into 2 groups, namely the SK and KD groups for odd semesters and even semesters. Each KD was given a proportional allocation of time. This annual program (Prota) had been made by the teacher and approved by the principal.

\section{b. Preparing the Semester Program (Promes)}

The semester program was a learning program that would be implemented in 1 semester. The semester program was in the form of a learning plan matrix for each KD for 1 semester. In this semester program, it could be known which month and week a KD would be delivered.

\section{c. Developing a Syllabus}

The syllabus was an Outline of the Lesson Program (GBPP) as a general learning guide. The content standards of both Competency Standards (SK) and Basic Competencies (KD) in the syllabus referred 
to the 2006 curriculum which had been developed into the Pengkol Elementary School Curriculum (KTSP). In the syllabus, besides containing SK and KD, also included indicators of KD achievement, learning materials, learning activities, assessment programs, time allocation, and general learning resources. This syllabus had been developed by the teacher. From this syllabus, would then be described in detail into a Learning Implementation Plan (RPP).

\section{d. Develop an Assessment Development Program}

The assessment development program was a learning assessment program that included procedures, techniques, and forms of assessment instruments. For example, a KD was planned for an assessment of the final test procedure with test techniques and the form of a description of the instrument. Because dance learning was dominated by practice, dance learning at Pengkol Elementary School was mostly used for performance test procedures with observation techniques and the form of the instrument was in the form of observation sheets according to the aspects to be assessed.

e. Preparing the Learning Implementation Plan $(R P P)$

The Learning Implementation Plan $(R P P)$ was a learning implementation program for each basic competency. Each basic competency could be done in one or more meetings. The RPP components included SK, KD, achievement indicators, learning objectives, materials, methods, media, and learning tools, teaching and learning activities (learning scenarios), learning resources, and assessments. RPP was a representation of the implementation of learning that would be carried out by the teacher at a meeting or faceto-face activity.

f. Develop assessment instruments and improvement/enrichment programs.

There were three kinds of assessment instruments which had been made by dance teachers, namely preliminary test instruments, 
in-process test instruments, and final test instruments. With this test, it would be known whether students had reached the Minimum Completeness Criteria (KKM) or not. The improvement program was a learning program for students who had not yet reached the KKM. While the enrichment program was a learning program which had been given to students who had exceeded the KKM.

g. Preparing the Learning Media and Tools

For learning dance at Pengkol Elementary School, there were available learning media in the form of tape, DVD/VCD player, sound system, microphone, LCD, television, and others provided in the art room. The art teacher also provided several tools in the form of VCDs and cassettes. The completeness of the dance costumes was provided by the teacher, while each student has their own sampur.

\section{Delivery Stage}

To find out the stage of delivery of dance learning at Pengkol Elementary School, the researchers conducted direct observations when the dance teacher was carrying out dance lessons. At this stage of delivery, it was divided into 3, namely initial activities, core activities, and final activities each with an allocation of 5 minutes, 50 minutes, and 25 minutes for each meeting (80 minutes). Each activity was as follow:

\section{a. Initial Activities}

Based on the results of observations when learning cultural arts takes place, in this activity the teacher began learning activities with:

1) Say greetings ( by saying "Assalamu 'alaikum warohmatullahi wabarokatu" or "Selamat Pagi" and continued to pray if the lesson was in the first hour;

2) Checking student's attendance by asking which students were not present at that time.

3) Arrange the seats if needed, when the students in the art room, the seats were arranged evenly lined up backward and to the side. 
4) Orally convey the competencies to be achieved, for example, students were able to perform the basic movements of a traditional Central Javanese dance, in this case, what had been studied at that time was the Gambiranom Dance.

5) Delivering orally the learning objectives, at that time was delivered through demonstrations and practice students could display the basic movements of the Gambiranom dance correctly.

6) Giving the initial test orally, at that time the teacher asked: "Apakah kalian ada yang pernah orang yang sedang menampilakan tari Gambiranom?" and "Apakah kalian tahu termasuk tari tunggal ataukah tari berpasangan tarian Gambiranom tersebut?"

7) Giving apperception and motivation, at that time the teacher gave an apperception that the gambiranom dance was a Central Javanese dance depicting a knight who was in love. This dance was a classic alus dance of man. Then the teacher motivated students to study this dance seriously in order to understand all the basic movements correctly.

\section{a. Core Activity}

In this activity, the delivery stage included elaboration, collaboration, and confirmation. In elaboration, students absorbed ongoing learning material. When the researcher observed the teaching and learning activities, the teacher had been shown the Gambiranom dance on the LCD screen. In this activity, the researcher observed various kinds of class activities by making observations and found that the teacher explained in detail the basic movements of the dance and then demonstrated in front of the students which included:

1) Head Movement, including

a) Pacak gulu godheg which was the chin was moved to the left and then pulled upright again.

b) Lenggut that was, where the chin/ beard was brought forward and then pulled back.

c) Ula nglangi that was, the neck was moved to the right and left (by inserting the chin in and then pulled up). 
2) Hands Movement, including

a) Nyekiting that was, the attitude of the thumb met the fingers to form a circle while the other fingers followed inward

b) Ngrayung that was, the attitude of the thumb was bent inward while the four fingers that were tightly together were perpendicular

c) Boyomangap that was, the attitude of the thumb should point forward while the other fingers should be close together

d) Nyempurit that was, the attitude of the thumb meeting the index finger in a circle while the other fingers were curved in the direction of the middle finger

3) Body Movement, including

a) Hoyog that was, body movements like being blown by the wind

b) Ngleyek that was, the movement of the body was placed to the left then towards the right

4) Foot Movement, including

a) Lumaksana that was, the movement of the walking foot

b) Kengser that was, the movement of the feet was moved to the right and to the left where the position of the foot opened and closed

c) Srisik that was, the movement of the feet on tiptoe and walking fast and small.

After that, the students followed these movements with the guidance of the teacher. After the guidance activity was complete, the teacher asked one of the students to display it in front of other students and the teacher would ask the student's opinion to be right or wrong the movements were displayed by the students in front of the class. To demonstrate in front of the class at that time there had been the collaboration between students or teachers and students. Then the teacher explained again about the Gambir Anom dance and concluded the essence of the subject matter at that time. At this stage, there had 
been confirmed. At this stage of core activity, teacher-student and students' interactions occurred with other students and at this stage, the transfer of knowledge occurred both from teachers to students and from learning resources (books, VCDs, or others) to students. In this core activity, the method was chosen by the teacher was also applied in learning. From the description above, it could be formulated that in the core activities occurred: Elaboration; the teacher explained or described the subject matter with the chosen method as listed in the lesson plan, for example, lectures, demonstrations, practices, and others. Collaboration; that was, there was good interaction between teachers and students or students with students through group discussions or class discussions, for example, as a dance teacher was done by asking one of the children to come forward and perform a dance, then the teacher asked for opinions or responses from other students. Confirmation; that was affirmation or justification where this was done by the teacher to provide the correct and firmly attached concept to students.

\section{b. Final Activity}

In the final activity, which teachers at Pengkol elementary school's did; Concluding the learning material, that was, the important things from the material were emphasized again to the students; Giving a final test of the lesson, by asking students to perform the dance movements that had been learned on that day; Giving assignments, which could be in the form of assignments to practice groups or other tasks related to the dance being studied and the teacher closed the lesson with greetings and continues with a prayer if the lesson was at the last hour.

\section{Practice Stage}

In dance learning at Pengkol Elementary School, the training stage was carried out both in face-to-face activities (KBM activities) according to the schedule and outside of lesson hours or schedules, for example in extracurricular activities (additional hours in the afternoon), group 
exercises, individual exercises at students' homes. After a subject matter was delivered, the teacher provided exercises so that students could really be master the material and were skilled at performing these dance movements, groups were formed which then these groups would practice independently which could be done at school or the home of members of the group. The Gambiranom dance had been performed by students at performances and recorded so that SD Pengkol had a recorded VCD and it could be duplicated by students to speed up material absorption and fluency. The teacher often did this stage more than one time because to be master the dance was not enough with just one meeting/face to face. So at this stage of practice required high motivation in students to be diligent master the dance movements that had been conveyed by the teacher.

\section{Performance Stage}

The purpose of the performance stage was to ensure that the learning material remains attached and was successfully applied. At this stage, it could be seen how far the exploration that had been carried out by students could be measured. The stage of performance in dance learning at Pengkol Elementary School was manifested in various activities, including: Assessment activities, when the teacher conducted an assessment in the form of daily tests, mid-semester tests, end-of-semester tests, grade promotions, and school exams. All forms of evaluation/assessment of dance learning were carried out with practice tests or performances, which were shown at several dance movements or performing dances that had been taught in their entirety and Other non-assessment activities; the performance stage other than assessment activities was often also carried out in other non-assessment activities for example in school anniversary activities, inter-class competitions, farewell/graduation activities, dance performances at local community celebration events such as sedekah bumi (cleaning the village), wedding party, and etc. From the results of interviews with researchers were both to the principal, teachers, and students of SD Pengkol, it was known that there were students who had appeared in these events. Performance activities liked this were very effective for developing students' 
competencies and would even foster a love for culture, especially dance. The government provided a curriculum in learning arts and culture, especially dance, which was used as a reference that could be used by cultural art teachers. In this study, Pengkol Elementary School was used as a place of observation where researchers obtained the data needed in this study. As a result, the various stages were provided by the curriculum were carried out and implemented by the cultural art teacher at Pengkol Elementary School. With the implementation of these various stages, the results were obtained were even more maximal considering the background of the students who also came from artists' families. Thus, the process of introducing and learning cultural arts, especially dance, could provide better results.

\section{CONCLUSION}

Learning cultural art (dance) at Pengkol Elementary School, Kaliori subDistrict, Rembang Regency uses the Education Unit Level Curriculum (KTSP) which refers to the 2006 curriculum. The dance teachers have implemented management methods, organizing cultural arts learning with dance teaching materials in stages : (1) preparation stage, (2) delivery stage, (3) practice stage, and (4) performance stage. Dance learning has a high supports both from the aspect of students, teachers, infrastructure, and the assessment system, even cultural art learning is explicitly stated in the school's vision, which is Piety, Achievement, and Cultured in the spirit of global excellence. The assessment of learning outcomes is carried out by the teacher in various ways including daily tests, mid-semester tests, end-semester tests, grade promotion tests, and school exams. Learning Assessment is carried out by the principal or supervisor. Cultural arts education is very important, especially dance learning in schools which has a good contribution to art education in Indonesia as well as character building in the form of appreciation control during learning. In addition, this learning also helps the development of local, national, and even global cultures. 


\section{REFERENCES}

Ahsani, E. L. F., \& Azizah, N. R. (2021). Implementasi Literasi Budaya dan Kewargaan untuk Mengembangkan Keterampilan SosialSiswa Madrasah Ibtidaiyah di Tengah Pandemi. Jurnal Pendidikan Kewarganegaraan, 11(01), 7-16. https://doi.org/http://dx.doi.org/10.20527/kewarganegaraan. v11i01.10317.

Agnew, P. W., Kellerman, A. S dan Meyyer, M. J. (1996). Multimedia in the classroom. Boston: Allyn and Bacon.

Depdiknas, 2007. Pedoman Permainan Berhitung Permulaan di Taman Kanakkanak, Jakarta: Dirjen Dikdasmen.

Khutniah, N., \& Iryanti, V. E. (2012). Upaya Mempertahankan Eksistensi Tari Kridha Jati Di Sanggar Hayu Budaya Kelurahan Pengkol Jepara. Upaya Mempertahankan Eksistensi Tari Kridha Jati Di Sanggar Hayu Budaya Kelurahan Pengkol Jepara, 1(1), 9-21.

Pradewi, S., \& Lestari, W. (2012). Eksistensi Tari Opak Abang Sebagai Tari Daerah Kabupten Kendal. Eksistensi Tari Opak Abang Sebagai Tari Daerah Kabupten Kendal, 1(1), 1-12.

Hasanah, H. (2017). TEKNIK-TEKNIK OBSERVASI (Sebuah Alternatif Metode Pengumpulan Data Kualitatif Ilmu-ilmu Sosial). At-Taqaddum, 8(1), 21. https://doi.org/10.21580/at.v8i1.1163

Hetty Tumurang, 2006. Pembelajaran Seni Anak Sekolah Dasar. Jakarta: Depdiknas.

Rahayuningtyas, D. R., Rizqi, P. A., Putri, R. F. M., Sawwama, A., \& Ahsani, E. L. F. (2021). Peran Guru Dalam Mempertahankan Cultural Heritage Indonesia Dalam Membentuk Karakter Siswa di Sekolah Indonesia Kuala Lumpur. PENSA : Jurnal Pendidikan Dan Ilmu Sosial, 3(April), 2737. https:/ / doi.org/https://doi.org/10.36088/pensa.v3i1.1126.

Syamsudin, A. (2014). 2882-8276-1-PB.pdf. In Jurnal Pendidikan Anak: Vol. iii.

S. Nasution. (1999). Metode Penelitian Naturalitik Kuantitatif. Tarsito.

Sugiyono. (1998). Metodologi Penelitian Administrasi. CV Alfabeta.

Soetopo, S. (2015). Pembelajaran Seni Di Sekolah Dasar. Jurnal Inovasi Sekolah Dasar, $2(1), 25-32$. 
Meier, Dare. 2002. The Accelerated Learning Handbook. Panduan Kreatifitas dan efektifitas merancang program pendidikan dan pelatihan. Bandung: Kaifa.

Moelong Lexy J, 2001 Metodologi Penelitian Kualitatif, PT. Remaja Rosda Karya: Bandung.

Moelong Lexy J, 2002, Metodologi Penilitian Kualitatif, Remaja Rosda Karya

Naisah. (2013). Pembelajaran Seni Budaya dan Keterampilan dengan Menggunakan Pendekatan Inkuiri di Sekolah Dasar. Artikel Penelitian Universitas Tanjung Pura, 1(1).

Kusumastuti, E. (2014). Penerapan Model Pembelajaran Seni Tari Terpadu Pada Siswa Sekolah Dasar. Mimbar Sekolah Dasar, 1(1), 7-16. https://doi. org/10.17509/mimbar-sd.v1i1.858

Soehardjo, A,J, 2012. Pendidikan Seni: Malang: Bayimedia Publishing.

Sustiawati, N. L., Suryatini, N. K., \& Mayun Artati, A. A. A. (2018). Pengembangan Desain Pembelajaran Seni Tari Di Sekolah Dasar Berbasis Localgenius Knowledge Berpendekatan Integrated Learning. Mudra Jurnal Seni Budaya, 33(1), 128. https:/ / doi.org/10.31091/mudra.v33i1.322. 
